\title{
Opplæringsstrategi for å understøtte de nasjonale retningslinjene for selvmordsforebygging
}

\author{
Ved Ewa Ness
}

\section{De nasjonale retningslinjene for selvmordsforebygging i psykisk helsevern ble utgitt i 2008. Nasjonalt senter for selvmordsforskning og - forebygging (SSFF) hadde som mål i 2008 å gjøre retningslinjene kjent, og å bidra til en vellykket implementering blant annet gjennom opplæringstiltak. Hva har vi gjort?}

For at retningslinjer skal bli vellykket implementert kreves det først og fremst ledelsesforankring. Lederne må støtte retningslinjene og fatte beslutning om å innføre dem og legge til rette for dette i form av opplæring. Artikkelforfatteren har sammen med sjefpsykolog og forsker Fredrik A. Walby og de regionale sentrene om vold, traumatisk stress og selvmordsforebygging (RVTS) holdt regionale dagskurs i de fem helseregionene høsten 2008; i Arendal, Bergen, Trondheim, Troms $\varnothing$ og Oslo. Kurset var primært rettet mot legespesialister og psykologspesialister. Det var lagt opp som et kurslederkurs og skulle gjøre deltakerne i stand til å holde kurs i retningslinjene i eget helseforetak. Kurset bestod av en kunnskapsoppsummering på feltet og en gjennomgang av retningslinjene der det var satt av god tid til spørsmål og dialog. I tillegg fikk deltakerne utdelt ferdige presentasjoner som de kunne bruke i eget foretak.

Ca. 200 fagfolk har gjennomgått kurset i høst. Evalueringene viste at de fleste var forn $\varnothing$ yde med utbyttet av kurset.

Kursledere lokalt bør være faglige ledere og ha klinisk legitimitet. Det betyr at de fleste kursledere i spesialisthelsetjenesten bør være legespesialister og psykologspesialister. Enkelte av punktene i retningslinjene omhandler miljøpersonalets utfordringer og bør undervises av de som ut $\varnothing$ ver miljøterapi i d $\varnothing$ gnavdelinger. Det legges nå opp til en modell der RVTS og SSFF kurser lokale kursledere som samarbeider med sentrale fageksperter ved RVTS og SSFF, når de trenger oppdatering. Tidligere har det vært holdt en rekke kurs på forskjellige steder i Norge på forespørsel. Nå er foresp $\varnothing$ rslene blitt så mange at det er vanskelig å dekke dem. Det er imidlertid gledelig at så mange fagfolk har satt dette viktige tema på dagsordenen. Ved å innføre en modell der det utdannes lokale kursledere og det tilbys regelmessig faglig oppdatering, er det mulig å nå alle avdelinger i alle landets helseforetak på en systematisk måte. Det første nasjonale kurset i klinisk suicidologi planlegges holdt høsten 2009.

\section{Hva trenger man opplæring i?}

Det anbefales at det etableres n $\varnothing$ dvendige rutiner for opplæring i de nasjonale retningslinjene for alt personale som arbeider klinisk, og at dette også sikres for alle nyansatte. Som eksempel holder artikkelforfatteren kurs ved Ullevål universitetssykehus to ganger i året i selvmordsrisikovurderinger for leger og psykologer, og avdelingene ved Psykiatrisk divisjon har som målsetting å holde ett kurs i året for alt klinisk personale. Erfaring viser at det er viktig med systematisk vedlikehold av kompetansen, og det anbefales også i de nasjonale retningslinjene for forebygging av selvmord $\mathrm{i}$ psykisk helsevern. Videre anbefales også at de enkelte helseforetak bruker forslagene til prosedyrer som er gjengitt i retningslinjedokumentet:

\section{Vurdering av selvmordsrisiko}

Opplæring i kartlegging av selvmordsrisiko

Opplæring i vurdering av selvmordsrisiko

Observasjon av pasienter i forbindelse med selvmordsrisiko

Melding av selvmord eller alvorlige selvmordsfors $\varnothing \mathrm{k}$

Oppfølging av etterlatte etter selvmord

- Oppfølging av pasienter som ikke møter til timeavtale

Fysisk sikring av døgnenheter i forhold til forebygging av selvmord

Dersom helseforetaket har egne prosedyrer på dette feltet, må disse oppdateres i tråd med de nasjonale retningslinjene.

Statens helsetilsyn gjennomf $\varnothing$ rer i 2008-2009 nasjonalt tilsyn med internkontroll ved distriktspsykiatriske sentre

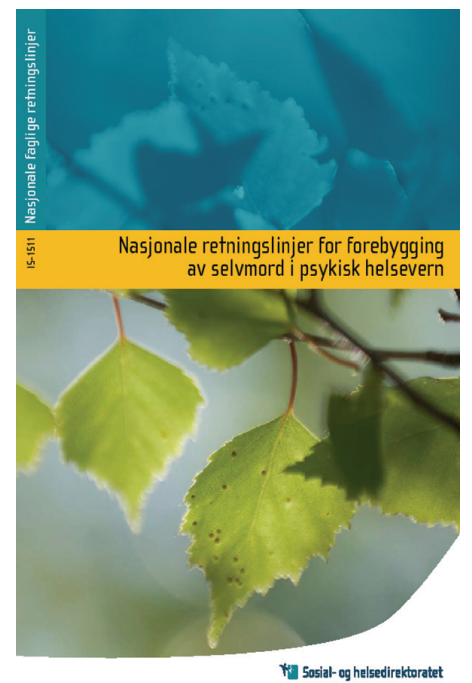

(DPS). Artikkelforfatteren er fagrevisor for tilsynet, og min erfaring så langt er at det er svært få helseforetak som har prosedyrer på dette området. Det gjenspeiler seg i manglende dokumentasjon av selvmordsrisikovurderinger i journalene. Et mål for det enkelte helseforetak burde være at alle enheter implementerer de nasjonale retningslinjene og prosedyrene innen 2009.

Retningslinjer, prosedyrer og opplæring gir ingen garanti for at pasientene får god selvmordsforebyggende behandling. Det anbefales derfor at helseforetakene selv gjennomfører kontroll på journaldokumentasjon for å se hva som faktisk gjøres i møte med den enkelte pasient. Det forutsetter at det som gjøres, er det som dokumenteres. Mange ledere blir overrasket over at praksis ved deres avdeling er forskjellig fra det som er besluttet i retningslinjer og prosedyrer.

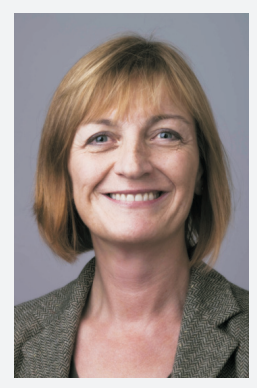

Ewa Ness er psykiater og fagsjef $\mathrm{v} /$ Psykiatrisk divisjon Ullevål universitetssykehus. Siden 1996 har hun vært leder for Psykiatrisk legevakt i Oslo. Hun er ansatt $\mathrm{i}$ en bistilling som seniorrådgiver v/SSFF med fokus på implementering av nye faglige retningslinjer for selvmordsforebygging i psykisk helsevern. 